\title{
A Technology Acceptance Model of common bean growers' intention to adopt Integrated Production in the Brazilian Central Region
}

\section{Ein Technologie-Akzeptanzmodell zur Absicht von Bohnenproduzenten, Integrierte Produktion im brasilianischen Zentralgebiet einzuführen}

\author{
Aluisio Goulart Silva ${ }^{1}$, Maurizio Canavari ${ }^{2 *}$, Katia Laura Sidali ${ }^{3}$
}

\author{
${ }^{1}$ Brazilian Agricultural Research Corporation (Embrapa), Ministry of Agriculture, Livestock, and Food Supply, Rodovia GO-462, Km 12, CEP \\ 75375-000 Santo Antônio de Goiás, Brasil \\ ${ }^{2}$ Department of Agricultural Sciences, Alma Mater Studiorum-Università di Bologna, Viale Giuseppe Fanin, 50, 40127 Bologna, Italy \\ ${ }^{3}$ Faculty of Economics, Free University of Bozen/Bolzano, Universitätsplatz 1, 39031 Bruneck, Italy \\ * Corresponding author: maurizio.canavari@unibo.it
}

Received: 7 February 2017, received in revised form: 14 October 2017, accepted: 16 October 2017

\begin{abstract}
Summary
The Brazilian government encouraged the Integrated Production (IP) farming system adoption to mitigate the negative environmental impacts of intensive bean production in irrigated areas of the Brazilian savanna. By ensuring food-safety and the use of sustainable agricultural practices, IP may strengthen national agriculture competitiveness. Regardless of the government efforts to promote IP in the main agricultural regions and among the largest food growers, only few slowly adopted it. Therefore, studying the process of technology adoption is important to identify possible problems that could affect adoption and diffusion of this farming system. We applied a Technology Acceptance Model (TAM) to explain the adoption and use of IP by the common beans growers from one of the most important bean production regions in Brazil. Ninety-three interviews were administered to different actors involved in beans production. A Structural Equation Model (SEM) following a confirmatory factor analysis (CFA) was used to identify the relationship between factors. The findings suggest that respondents have positive perceptions toward adopting IP. Perceived usefulness has a positive impact on attitude, and attitudes affect behavioral intention. However, the proposed model only partially explains IP adoption intentions.
\end{abstract}

Keywords: technology transfer; producers' behavior, Technology Acceptance Model, Structural Equation Model, common beans

\section{Zusammenfassung}

Die brasilianische Regierung ermutigt die Einführung der Integrierten Produktion (IP) in der Landwirtschaft, um die negativen Umwelteinflüsse der intensiven Bohnenproduktion in den bewässerten Regionen der brasilianischen Savanna zu minimieren. Durch die Sicherstellung der Nahrungsmittelsicherheit und die Anwendung nachhaltiger landwirtschaftlicher Verfahren kann mithilfe der IP die Wettbewerbsfähigkeit der nationalen Landwirtschaft gestärkt werden. Dennoch, ungeachtet der Anstrengungen der Regierung, die IP in Hauptagrargebieten und bei den größten Lebensmittelproduzenten zu bewerben, übernehmen nur wenige diese. Deshalb ist eine Untersuchung des Prozesses der Technologieadaption wichtig, um mögliche Probleme, welche die Annahme und Verbreitung dieses Agrarsystems beeinflussen, zu identifizieren. Wir haben ein Technologieakzeptanzmodell (TAM) verwendet, um die Annahme und Verwendung von IP durch die Bohnenproduzenten in einer der wichtigsten Produktionsregionen von Bohnen in Brasilien zu erklären. Dreiundneunzig Interviews wurden mit verschiedenen Akteuren im Bereich der Bohnenproduktion durchgeführt. Ein Strukturgleichungsmodell (SEM) wurde nach einer konfirmatorischen Faktoranalyse (CFA) angewendet, um die Beziehung zwischen den Faktoren zu identifizieren. Die Ergebnisse zeigen, dass die Antwortenden eine positive Auffassung hinsichtlich der Annahme der IP haben. Eine wahrgenommene Nützlichkeit hat einen positiven Effekt auf die Einstellung und diese beeinflusst die Verhaltensabsicht. Dennoch, das vorgeschlagene Modell erklärt nur teilweise die Absicht, die IP einzuführen.

Schlagworte: Technologietransfer, Produzentenverhalten, Technologieakzeptanzmodell, Strukturgleichungsmodell, Bohnen 


\section{Introduction}

\subsection{Integrated Production in Brazil}

The concept of Integrated Production (IP), as a sustainable production system, is relatively new in Brazil; it has been applied for approximately two decades. One of the first experiences with IP in Brazil was with fruit crops, in 2001. Later, in 2008-2009, grains and livestock became part of the pool of IP projects (Andrigueto et al., 2009). During the same period, the development of standards for common beans had the objective to mitigate the negative environmental side effects of intensive dry bean production in irrigated areas of the Brazilian savanna, in the center of the country.

The IP had its legal framework established in 2010 by the Normative Instruction No 27 of 08/30/10 (BRASIL, 2010). Since then, the Brazilian government, throughout its official Research, Development, and Extension agencies, has promoted the IP to satisfy the governmental regulations for sustainability (BRASIL, 2015).

Despite the government's effort to establish IP in the main agricultural regions for the most important agro-food products, few targeted communities of producers have participated in this kind of project at the ideal rates and intensity, or for the expected length of time. Some hypotheses that explain this negative scenario could be certain regional differences such as different biomes, inequality among agricultural segments (small scale agriculture versus large scale agriculture), and crop interest, due to which some of them are targets to export and others to the domestic market (Souza Filho et al., 2011).

In this context, this study tries to answer some questions: (a) although the Government has been investing a lot of money and efforts to encourage a greater production of quality/safe agro-foods, why don't majority of farmers adopt the IP system? Which factors are responsible for this undesirable situation? (b) Are growers willing to adopt IP aiming to produce dry beans, in the irrigated areas of the Brazilian savanna?

Therefore, studying the process of technology adoption (TA) became an important issue to elucidate or to predict possible problems that could affect the adoption and afterwards the diffusion of the available offered technologies.

The primary objective of the present study was to determine if the Technology Acceptance Model (TAM) could provide an adequate explanation of adoption and use of IP by common beans' farmers. An additional aim was to determine the extent to which some economic, social, technical, environmental, and market factors influence the decision making, TA and usage of the bean's growers. For the purpose of the present study, the TAM was tested with IP understood as a bundle of technologies.

\subsection{Factors that influence technology adoption (TA) in agriculture}

Several prior studies seek to understand the individual decision-making process of adoption and diffusion of technology patterns in different groups of producers. It is a multifactorial problem linked to the context of technology applicability and user's characteristics. Most of the studies were conducted focusing on the economic concerns influencing the decision-making and TA relative to production maximization and profitability (Garsson et al., 1988; Flett et al., 2004; Aubert et al., 2012).

When an innovation is easy to adopt with clear economic advantages, low complexity, and without other intervening considerations, then models based only on economic aspects adequately explain the producer's behavior towards adoption (Sinden and King, 1990). However, in the reallife, this kind of situation is not easy to be found.

Thus, even though there is economic evidence motivating the farmers to adopt certain innovations, they probably will not adopt taking into account only this criterion. One of the problems of using neat economic models is that the full complexity of producers' behavior and motivation towards TA probably cannot be captured (Flett et al., 2004). Technology in agriculture can be adopted individually or in an aggregate level of use of a particular technology, among a certain group of producers or in one specific area. Or else, one can adopt a singular technology or a package of technologies that connects to other complementary agricultural practices or inputs that should be introduced together, in a bundle with the main technology.

In addition, it is important to consider if the technology is divisible or indivisible. If one considers IP as a bundle of sustainable agricultural practices, its adoption cannot be considered divisible due to the concepts and principles of IP certification (IOBC, 2004).

Time dimension is another important element on the adoption and diffusion process. The relative speed with which members of a social system adopt an innovation in a given time period refers to the rate of adoption. Those who are relatively earlier in adopting the new ideas than others are called innovators (Rogers, 1995). 
Parvan (2011) lays emphasis on the most common factors used to explain the variability seen in agricultural TA:

- farm size

- human capital

- labor availability

- risk exposure and capacity to bear risk

- tenure

- credit constraints, and

- access to commodity markets.

Several studies have indicated that the larger the farm (measured by the number of full-time workers), the more likely it is to adopt a certain technology (Daberkow and McBride, 2003; Hussain et al., 2011; Parvan, 2011; Li et al., 2013). While larger farms adopt lumpy (non-divisible) and divisible technologies faster than smaller farms, the latter adopt divisible technology more intensively, and may eventually adopt the lumpy technology. Probably because larger farmers are more likely to be able to invest money, time and learning in order to use the technologies than smaller farmers (Adrian et al., 2005).

Human capital relates to socio-demographic characteristics. Prior studies (Daberkow and McBride, 2003; Adrian et al., 2005; Hussain et al., 2011; Souza Filho et al., 2011) showed that the higher the growers' age, the lower the intention of TA; and the higher the growers' level of education, the higher the intention of adoption. Farmers with higher education possess higher specific abilities and are able to adjust faster to farm and market conditions. Consequently, they usually adopt new technologies more rapidly as compared to those with lower level of education (Rogers, 1995; Parvan, 2011).

The shortage or surplus of labor availability on the area targeted with the technology also affects the adoption process. Higher labor supply is associated with higher rates of adoption of labor-intensive technologies; the inverse is also true. Moreover, it is also important to consider whether the technology is labor saving or labor-intensive (Parvan, 2011).

Risk exposure and capacity to bear risk (subjective risks such as uncertainty over yield, or objective risks such as occurrence of pests and diseases) is a crucial factor of aversion on adopting high technologies (Moser and Barrett, 2003). Lee et al. (2011) note that increased access to credit sources can help farmers overcome short-run liquidity constraints and increase TA. Souza Filho et al. (2011) mention that producers that have credit access are more likely to adopt new technologies due to their ability at managing the risk regarding the production and commodity prices.

Access to inputs of biological control and commodity markets is another essential factor. If farmers are not secure in their access to the basic resources, or are uncertain over the product price applied by the commodity market, the adoption process could be negatively influenced (Parvan, 2011).

Studies suggest, the likelihood that a farmer will continue using an agricultural technology relates to the frequency of contact with trained extension workers, especially for technically complex technologies. Moreover, contact with neighboring farmers who possess knowledge of the proposed technology also increases the adoption likelihood (Moser and Barrett, 2003).

Souza Filho et al. (2011) state that farming experience is a relevant factor for adopting sustainable practices, including tools and certification schemes focused on environmental management and food safety. Moreover, the higher the farming experience, the higher the intention of TA. In this study, we assumed this positive effect. Contrary, Adrian et al. (2005) as well as Daberkow and McBride (2003) have identified that the higher the farming experience, the lower the intention of TA.

The use of land with diverse types of crops and/or livestock also influences adoption, as suggested by $\mathrm{Li}$ et al. (2013) and Ascough II et al. (1999). We assumed that the presence of livestock activity affects the IP adoption negatively in this research context.

Sterns and Codron (2001) suggest investigating different kinds of incentives affecting the intention of adoption IP. Clear incentives and official policies such as access to credit for adopting sustainable technology; receiving a premium price for IP certified beans; receiving subsides to acquire IP's supplies such as biological control agents can influence the intention to adopt positively (Sterns and Codron, 2001).

There is no evidence of published studies to determine the lack of IP implementation in Brazil or other countries. Likewise, there have been few published studies within the past 10 years to conclusively determine why Integrated Pest Management (IPM) implementation-the cardinal element of IP-continues to be an underutilized practice in pest control (Van den Berg and Jiggins, 2007). For instance, in the United States, time (lack of), labor, and competing obligations are considered potential barriers to adopting IPM techniques (Vommi et al., 2013). 


\section{Theoretical Background}

In this study, the Technology Acceptance Model (TAM) developed by Davis (1989) was applied to measure the intention of IP adoption (Figure 1).

Davis (1989) based his model on the psychological model known as the Theory of Reasoned Action (TRA). The latter is centered on the assumption that the individual attitude has an important role in determining the behavior towards adopting a certain technology (Ajzen and Fishbein, 1980). TAM is considered a more flexible method because it permits to capture some important psychological elements that influence producers in adopting or not adopting the technology. This model has been used to explain both short-term (acceptance and adoption) behaviors and long-term (usage) behaviors (Morris and Venkatesh, 2000). The foundation of TAM is that users will not likely receive a system or technology favorably if it does not help them perform their jobs in spite of careful implementation efforts. TAM permits to demonstrate the simultaneous effects of potential TA by users' perceptions of usefulness (PU) and ease of use (PEOU) on both the intention to adopt technology and the actual use of technology.

Davis (1989) defines PU from the word useful that means "capable of being used advantageously" while PEOU follows the definition of ease that means "freedom from difficulty or great effort". In TAM context, attitude toward using (ATT) is "an individual's positive or negative feeling about performing the target behavior", and behavioral intention (INT) is "the degree to which a person has formulated conscious plans to perform or not perform some specified future behavior".

According to Davis (1989) and Chin and Todd (1995), PU directly and positively affects the users' behavioral intention to use; similarly, PEOU has a positive effect on the end-users' attitude and behavioral intention. Adrian et al. (2005) state that the more useful the technology is perceived by the potential user, the more likely it is to adopt it. Fishbein and Ajzen (1975) and Davis (1989) affirm that attitude towards usage has a positive effect on intention to use the technology. As shown in the remainder of this article, the authors use a simplified version of Davis' model focusing on the essential role of PU and PEOU as antecedents of both attitude (ATT) and intention to use technology (INT) (Figure 2); however, we do not include "external variables" and "actual system used" in our model. Thus, similar to the work of Flett et al. (2004), we consider PU and PEOU as fundamental determinants of farmers' attitude and stated intention to adopt a new technology. Moreover, while Flett et al. (2004) use discriminant analysis to ascertain the relative importance of PU and PEOU on users' acceptance of a new technology, in the following, we will replicate the model of Davis (1989) by using a structural equation model in order to simultaneously detect the effects of the latent constructs of PU and PEOU on both attitude (ATT) and intention to use technology (INT).

So far, our hypotheses respect the original direction of the relationships of latent variables of the original model of Davis (1989) as it follows:

$\mathrm{H} 1$ : the higher the users' perceptions of usefulness (PU) of a technology, the higher the stated intention (INT) to adopt such technology.

H2: the higher the users' attitude (ATT) toward a technology, the higher the stated intention (INT) to adopt such technology.

$\mathrm{H} 3$ : the higher the users' perceptions of ease of use (PEOU) of a technology, the higher the users' attitude (ATT) toward the technology.

$\mathrm{H} 4$ : the higher the users' perceptions of ease of use (PEOU) a technology, the higher the users' perceptions of usefulness (PU) of the technology.

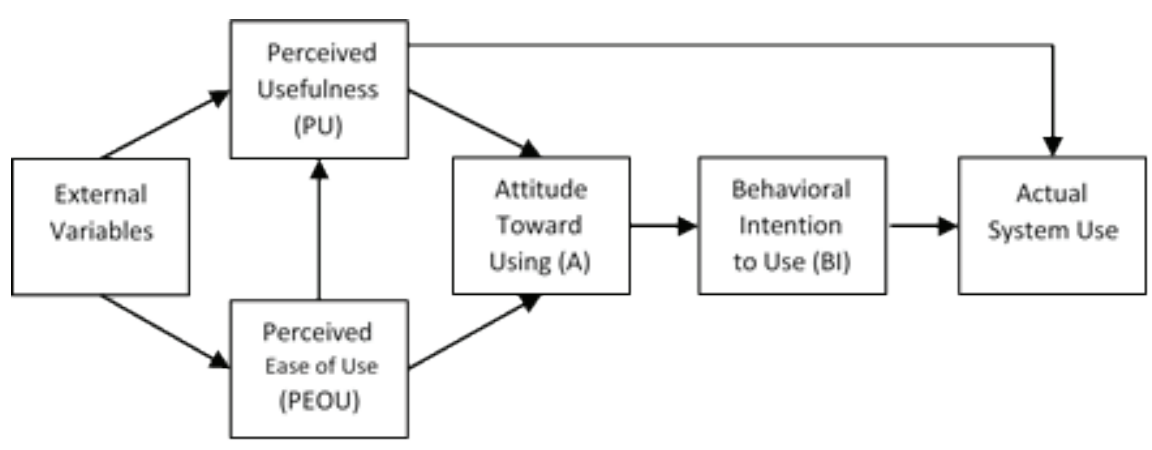

Figure 1. Technology Acceptance Model (TAM); Source: Davis (1989)

Abbildung 1. Technologieakzeptanzmodell (TAM); Quelle: Davis (1989) 
$\mathrm{H} 5$ : the higher the users' perceptions of usefulness (PU) of a technology, the higher the users' attitude (ATT) toward the technology.

\section{Materials and Methods}

\subsection{Data Collection and Survey Procedures}

Data were collected in two different stages, a qualitative and a quantitative phase. The qualitative phase was developed between October 2013 and February 2014 with the objective to elicit the salient beliefs for each latent variable. Ten beans' growers and agronomists were interviewed; all of them had prior experience with IP only in a pilot spot, since IP is not yet an applied technology by growers. A structured questionnaire with open-ended questions was administered to the target sample in one of the most important regions in terms of beans' production in the Brazilian central region. The questionnaire was structured in four sections plus an additional section to collect some personal and professional data about the respondents. The type of questions per sections are described as follow:

(1) questions about technical aspects related to IP adoption;

(2) questions aiming eliciting the economic advantages and disadvantages in adopting IP;

(3) questions to elicit some institutional relevant factors that can influence IP adoption;
(4) questions involving some market aspects and other additional issues.

The interviews were recorded and then transcribed. Afterwards, content analysis was applied to summarize the respondent's impressions and their salient beliefs for each construct. The results were used to construct the quantitative phase.

The quantitative phase was performed using a structured questionnaire constructed in three sections: (1) preliminary questions about the respondent's knowledge on IP; (2) questions related to TAM's constructs; (3) respondents' demographic data. The interviews started with a "cheaptalk" script in order to removes hypothetical bias for growers relatively ignorant of the evaluated technology (Lusk, 2002). In fact, this phase was crucial because some producers were not familiarized with integrated production. Actually, the principal elements of the integrated production system were introduced as a new concept of sustainable production. In this manner, the objective of "cheap-talk" was explaining about the integrated production system to the respondents.

The questionnaire was designed considering its validation and reliability (Hair et al., 2006).

Two diagnostic measures were used to assess the internal consistency on the dataset. One related to each separate item, including the item-to-total correlation and the interitem correlation. In this case, the parameter exceeded by 0.50 in the item-to-total correlations and 0.30 in the inter-

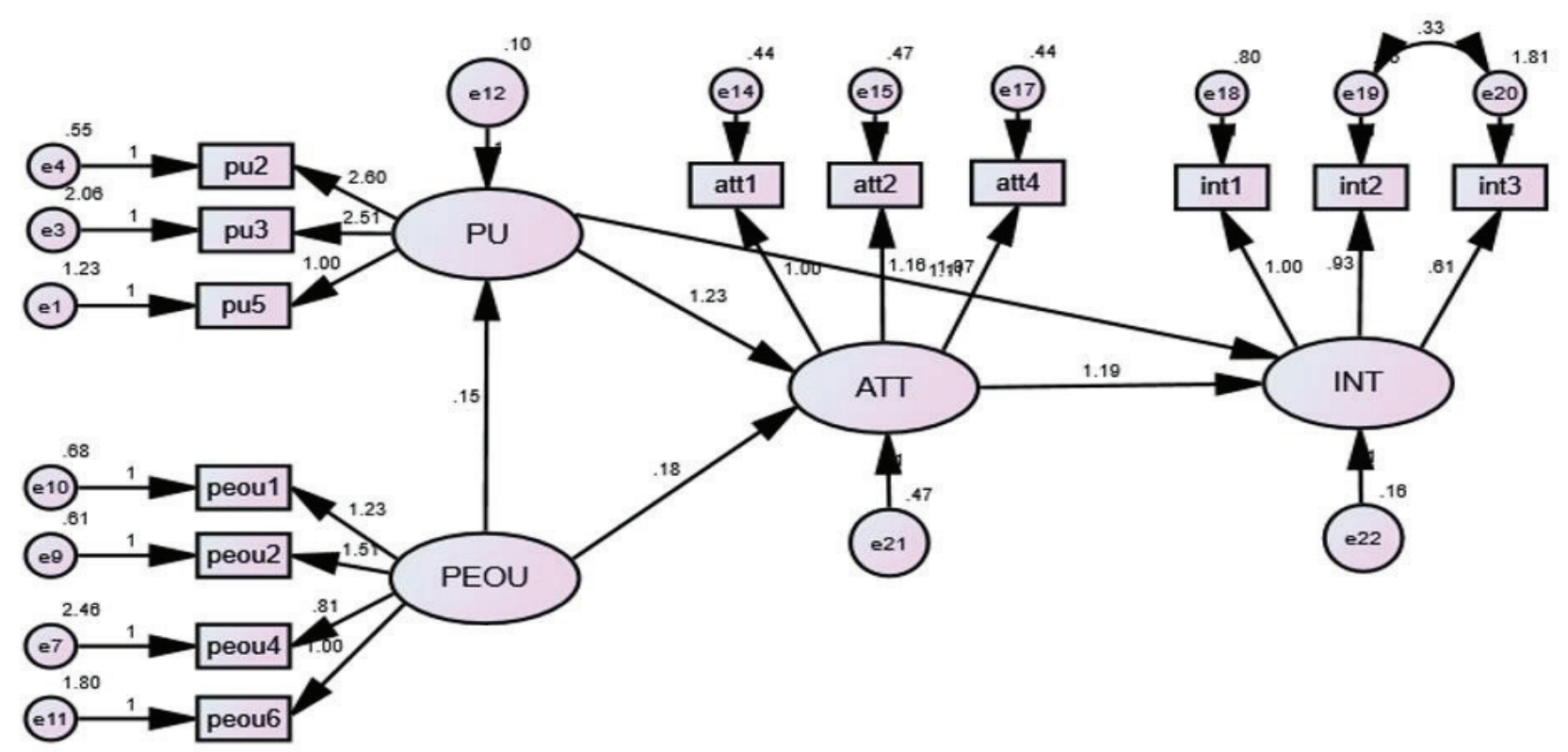

Figure 2. Path diagram

Abbildung 2. Pfaddiagramm 
item correlations. The second diagnostic measure related to the entire scale. In this case, the consistency of the entire scale was verified by the reliability coefficient with Cronbach's Alpha; values of 0.60 to 0.70 deemed the lower limit of acceptability (Hair et al., 2006).

A pilot survey was first administered to 38 beans' producers and agronomists. Afterwards, the collected data were evaluated in terms of their reliability, and adjustment of some items were made in order to achieve a Cronbach's alpha statistic equal to 0.70 or greater.

The final questionnaire was administered face-to-face by the researcher and trained agronomists from the research region, comprising seven municipalities located in the same region of the qualitative research. Ninety-three producers, consultants (agronomists and technicians), and last year agronomy's students were interviewed during December 2014 and February 2015, aiming to measure the variables of the research structural model. Unfortunately, the harvest season associated with the rainy weather did not contribute to get higher number of respondents. However, according to Francis et al. (2004), a sample size of 80 would be acceptable to assume at least a moderate effect using multiple regression approach.

The interviews started with a 'cheap-talk' script in order to reduce hypothetical bias (Lusk, 2002) because some producers were not familiar with IP.
Davis (1989) suggests that six items for each perceptual variable would be adequate to achieve acceptable reliability levels while maintaining adequate validity levels. Aubert et al. (2012) used six items per construct as an upper limit in order to minimize the number of questions; as a lower limit, they have used three items to guarantee the statistical procedures and give the flexibility to remove an item to improve reliability.

Fishbein and Ajzen (1975) recommend using a bipolar scale that represents a probabilistic rating of the concept, on scales such as likely-unlikely or agree-disagree, particularly to measure the concept "behavioral intention".

In the present study, we followed this recommendation and a seven-point scale was applied with structure very similar to that used by other authors such as Davis et al. (1989), Silva (2005), Alves da Costa Filho et al. (2007), and Folorunso and Ogunseye (2008).

\subsection{Data analysis}

A confirmatory factor analysis (CFA) was applied to identify the relationship between the factors and the measurement variables. The latter were derived by the abovementioned literature. Table 1 depicts all the measurement variables used for each of TAM's latent variables in the present study.

Table 1. Items of the TAM model

Tabelle 1. Begriffe des TAM Modells

\begin{tabular}{|c|c|c|}
\hline Latent variables & Measurement variables (items) & 7 points scale \\
\hline \multirow{3}{*}{ PU } & By using IP in my farm, the agronomic effectiveness would improve. & (1) Extremely unlikely $\rightarrow$ Extremely likely (7) \\
\hline & By using IP in my farm, the costs of inputs would decrease. & (1) Extremely unlikely $\rightarrow$ Extremely likely (7) \\
\hline & I believe IP can bring more benefits to the environment than conventional systems. & (1) Extremely unlikely $\rightarrow$ Extremely likely (7) \\
\hline \multirow{5}{*}{ PEOU } & It will be easy for me to learn and apply most of the IP practices. & (1) Extremely unlikely $\rightarrow$ Extremely likely (7) \\
\hline & $\begin{array}{l}\text { It will be easy for me to understand and apply the IP standards for common beans' } \\
\text { production. }\end{array}$ & (1) Extremely unlikely $\rightarrow$ Extremely likely (7) \\
\hline & $\begin{array}{l}\text { It will be easy for me understand and apply the IP standards for common beans' pro- } \\
\text { duction. }\end{array}$ & (1) Extremely unlikely $\rightarrow$ Extremely likely (7) \\
\hline & $\begin{array}{l}\text { It will be easy for me to use IP with the present biological control agents and other IPM } \\
\text { supplies available in my region. }\end{array}$ & (1) Extremely unlikely $\rightarrow$ Extremely likely (7) \\
\hline & I would find IP easy to use for producing common beans. & (1) Extremely unlikely $\rightarrow$ Extremely likely (7) \\
\hline \multirow{3}{*}{ ATT } & I would say that my overall opinion of IP system is $(\ldots)$ & (1) Extremely unfavorable $\rightarrow$ Extremely favorable (7) \\
\hline & I $(\ldots)$ the idea of using IP in my farm. & (1) Extremely dislike $\rightarrow$ Extremely like (7) \\
\hline & Using IP system in my farm is an (...) decision. & (1) Extremely negative $\rightarrow$ Extremely positive (7) \\
\hline \multirow{3}{*}{ INT } & I intend to use IP as my farming system. & (1) Extremely unlikely $\rightarrow$ Extremely likely (7) \\
\hline & I would recommend the IP system adoption for other farmers in my region. & (1) Extremely unlikely $\rightarrow$ Extremely likely (7) \\
\hline & I would also adopt IP if the neighboring farmers adopt. & (1) Extremely unlikely $\rightarrow$ Extremely likely (7) \\
\hline
\end{tabular}


CFA is a procedure used to test hypotheses about the structure of a data set. To proceed with the CFA, we used the technique of structural equation modeling (SEM) that is the most used statistical technique to estimate TAM (Kline, 2011).

SEM provides the appropriate and most efficient estimation for a series of separate multiple regression equations estimated simultaneously. In practice, SEM relates the hypothesized model's constructs known also as latent variables that are concepts that can be represented by observable or measurable variables. It is measured indirectly by examining the consistency among multiple measured variables or indicators.

The two basic components that characterize the SEM are the path model, which relates independent to dependent variables, even when a dependent variable becomes an independent variable in other relationships; and, the measurement model that enables the analyst to use several variables or indicators for a single independent or dependent variable (Hair et al., 2006).

The SEM was analyzed using the software IBM AMOS ${ }^{\circ}$ 21. The maximum likelihood estimation (MLE) was applied because it is more efficient and unbiased for multivariate normality assumption. The implied null hypothesis of SEM is that the observed sample and SEM estimated covariance matrices are equal, meaning that the model fits perfectly. Several statistical tests were used to determine the measurement model and specific evidence of construct validity by using goodness-of-fit (GOF) rates.

\section{Results}

\subsection{Sample Characteristics}

Descriptive statistics analysis was used to present the respondents' socio-demographic characteristics as well as farm structure. The results indicate that $86 \%$ of the respondents were male. Regarding the respondents' age, $34.4 \%$ were aged in the range $18-25$ years; $23.7 \%$ aged in the range $26-35$ years; $15.1 \%$ between $36-45$ years; $12.9 \%$ between $46-55$ years, and $12.9 \%$ were included in the range of 56-65 years. Only $1.1 \%$ of respondents were aged 66 years or older. The same range of ages normally applied by the Brazilian Institute of Geography and Statistics (IBGE) was used. The level of education of majority of them $(51.6 \%)$ was equivalent to agricultural technicians. Regarding students, 9.4\% were farmers or farmers' offspring. Regarding job occupation, almost 36\% were farm- ers, 34.4\% last year agronomy's students and other categories, $10.8 \%$ agricultural technicians, $9.7 \%$ farm managers, and $8.6 \%$ agronomist consultants. Excluding farmers, all the other respondents were selected considering that they influence the decision-making process of the growers. Although the average respondents' experience with agriculture is around 15 years, only $22.6 \%$ of them have heard about IP. It was expected since IP is not yet applied. Their self-evaluation about the knowledge of IP was 5.6 points in a scale from 1 to 10 , indicating an average knowledge. The type of land use of the farms showed that almost $70 \%$ was dedicated to mixed crops, $28 \%$ to crop and livestock, and only $2.2 \%$ to single crops. Farm size, average area for beans production, and average yield were eliminated from the dataset because most of the respondents do not have that information or preferred not to answer.

\subsection{Respondents' perceptions toward adopting IP}

Based on descriptive statistics (see Appendix A), the conceptual meaning of the four factors of the confirmatory factor analysis was analyzed by observing the items that underlie each of them:

Factor 1, labeled "perceived usefulness" (PU) contained three items referring to the degree to which a person believes that using a particular technology will enhance his or her job performance. It had a Cronbach's Alpha of 0.722 and a composite reliability value of 0.545 . Factor 2 was labeled "perceived ease of use" (PEOU) and included four items concerning the degree to which a person believes that using a particular technology will be free of effort. This factor had a Cronbach's Alpha of 0.730 and a composite reliability value of 0.725 . Factor 3 was "Attitude" (ATT) and consisted of three items referring to the evaluative aspect of a person's belief concerning the usage of a technology. It had a Cronbach's Alpha of 0.896 and a composite reliability value of 0.845 . Finally, the last factor was labeled "stated intention" (INT) and was made up of three items referring to the declared intention to use a technology. It had a Cronbach's Alpha of 0.783 and a composite reliability value of 0.777 .

One can say that the respondents positively perceived practically all the indicators building the latent variables considered in the model, except for PEOU.

The means of the PU items ranged among 5.2-6.0, indicating an average positive perception about the IP usefulness. Overall, the respondents perceived IP as a useful production system. They believed that IP could bring more 
environmental benefits as compared to the conventional system, as well as improve the agronomic efficiency because it was based on good agricultural practices, and it was an important component of agronomic records, which contributed to a better production's control. Moreover, they had the perception of cost reduction with inputs, as confirmed by Silva et al. (2012).

In terms of the PEOU items, ease of learning and applying IP practices, and the comprehension and norms' application did not seem to be difficult to put in practice, as per the respondents' perception, probably because these items relate to training programs and mandatory rules that are easier to control. However, the respondents were not sure whether it would be easy to produce beans by using IP. One can say that this result could be related with the other two that are the availability and access of biological products and technical support services to implement IP. Respondents, already in the qualitative phase of the study, observed the lack of bio products in the market, as well as some strategic technical support services to help the decision-making process, such as a pest and disease alert system.

Furthermore, the respondents showed a somewhat negative perception when they were asked whether it could be possible to apply IP without a full-time agronomist. One can infer that the respondents perceived some level of difficulty to use IP without a good technical assistance. This result is convergent to the known fragility of the public extension services available to the producers and the technical capacity of the local technicians in IP issues. Moser and Barrett (2003) highlighted the importance of the frequency of contact with trained extension workers so that the farmer continue using complex technologies such as IP. The same authors also evidenced that the contact of farmers with neighbors, who possess knowledge of the proposed technology, also increased the adoption likelihood. The results showed a tendency in this same way, that is, farmers stated intention to accept a technology is positive whenever their neighbors adopt IP. Moreover, it was slightly likely that they would recommend other growers to adopt IP. One can infer that the success of IP adoption depends on the growers' cohesion.

Overall, respondents demonstrated a slightly favorable attitude toward IP adoption, indicating that they would adopt IP to produce common beans in the following 5 years.

\subsection{Measurement Model}

The model was tested using IBM AMOS ${ }^{\bullet} 21$. Overall, it consisted of 34 parameters, from which 13 were observed variables (i.e., items indicators) and four were latent variables. Among the latter, two were exogenous (PU, PEOU) and two were endogenous (ATT, INT). The path diagram is illustrated in Figure 2.

Table 2 depicts the goodness-of-fit indices considered in the model fit examination. The recommendation is using

Appendix A. Measurement variables, descriptive statistics and Cronbach's alpha

Anhang A. Gemessene Variable, beschreibende Statistik und Cronbachs Alpha

\begin{tabular}{|c|c|c|c|}
\hline Latent variables & $\begin{array}{c}\text { Descriptive Statistics } \\
\text { Measurement variables (items) }\end{array}$ & Mean & Std. Deviation \\
\hline \multirow{3}{*}{$\begin{array}{c}(\mathrm{PU}) \\
\text { Perceived Usefulness } \\
(0.722)^{*}\end{array}$} & Benefits to environment & 6.0 & 1.1 \\
\hline & Improve agronomic efficiency & 5.7 & 1.1 \\
\hline & Reduce costs with inputs & 5.2 & 1.6 \\
\hline \multirow{4}{*}{$\begin{array}{c}\text { (PEOU) } \\
\text { Perceived Ease of Use } \\
(0.730)^{*}\end{array}$} & Easy to learn and apply IP practices & 5.7 & 1.2 \\
\hline & Easy to comprehend and apply the norms & 5.3 & 1.4 \\
\hline & Easy to apply with support services & 4.5 & 1.6 \\
\hline & Can apply without a full-time agronomist & 3.6 & 2.1 \\
\hline \multirow{4}{*}{$\begin{array}{l}(\text { ATT }) \\
\text { Attitude } \\
(0.896)^{*}\end{array}$} & Overall opinion of IP & 5.7 & 1.0 \\
\hline & The decision of using IP & 5.7 & 1.1 \\
\hline & The choice of using IP & 5.6 & 1.2 \\
\hline & The idea of using IP on the farm & 5.5 & 1.2 \\
\hline \multirow{3}{*}{$\begin{array}{c}(\mathrm{INT}) \\
\text { Behavioral Intention } \\
(0.783)^{*}\end{array}$} & Would recommend IP for other growers & 5.4 & 1.4 \\
\hline & Would adopt if the neighbors adopt & 5.2 & 1.5 \\
\hline & Have the intention to use IP in the next 5 years & 5.0 & 1.6 \\
\hline
\end{tabular}


three to four fit rates, and at least one incremental and one absolute index, in addition to the $\chi 2$ value and the associated degrees of freedom (Hair et al., 2006). Both CFI (comparative fit index) and RMSEA (root mean square error of approximation) are usually reported in addition to the $\chi^{2}$ value and the degrees of freedom $(\mathrm{DoF})$, to evaluate the goodness of fit of the overall model.

As shown in Table 2, the Chi-square statistic (59.694) was high and not significant ( $\mathrm{p}$-value 0.45 ), as expected. It means that there was no discrepancy between the observed covariance matrix and the estimated one. Considering that the implied null hypothesis of SEM was that the observed sample and SEM estimated covariance matrices are equal, these results were in the correct direction, but additional indicators must be verified to support this general impression of the goodness-of-fit since the Chi-square is sample size sensitive.

Analyzing the values of GFI $=0.912, \mathrm{CFI}=0.998$ and RMSEA $=0.011$, one could conclude that the model fit the sample data relatively well. GFI (goodness of fit index) measures the goodness-of-fit between the hypothesized model and the observed covariance matrix. CFI indicates the discrepancy between the data and the hypothesized model. Both GFI and CFI are indicators that are less sensitive to sample size. RMSEA, in turn, indicates the discrepancy between the hypothesized model and the population covariance matrix, although it is more useful in large sample size or large number of variables. Finally, the ratio
Table 2. Model fit summary

Tabelle. Zusammenfassung der Modellgüte

\begin{tabular}{lcc}
\hline Measures & Estimated Model & Acceptable values \\
\hline Chi-square & 59.694 & the lower the better \\
DoF & 59 & - \\
p-value & 0.45 & the higher (non-significant) the better \\
GFI & 0.912 & $\geq 0.90$ \\
CFI & 0.998 & $\geq 0.90$ \\
RMSEA & 0.011 & $<0.080$ \\
CMIN/DoF & 1.012 & $1-5$ \\
\hline
\end{tabular}

between the $\chi 2$ value and degree of freedom, indicated by CMIN, indicates an acceptable value.

Additionally, the standardized residual covariance matrix can be used in an ultimate analysis. According to Byrne (2009), values below 2.58 suggest a good consistency between the theoretical model and the sample. There was no value greater than 2.58 , as shown in Table 3 .

\subsection{Hypotheses testing}

Tables 4 and 5 focus on the structural model and present both the hypotheses tested and the standardized coefficients for each of the relevant paths. Focusing on the sign of the coefficients, the hypothesized relations among variables are confirmed by the findings.

Table 3. Standardized Residual Covariances Matrix

Tabelle 3. Standardisierte Residuen-Kovarianzmatrix

\begin{tabular}{|c|c|c|c|c|c|c|c|c|c|c|c|c|c|}
\hline & $\begin{array}{l}\circlearrowright \\
0 \\
\text { 된 }\end{array}$ & $\stackrel{m}{2}$ & $\ddot{m}$ & $\stackrel{\oplus}{\oplus}$ & $\bar{\nabla}$ & 艺 & z & $\bar{z}$ & $\begin{array}{l}5 \\
0 \\
0 \\
\text { 뙤 }\end{array}$ & 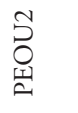 & $\begin{array}{l}\stackrel{+}{2} \\
\stackrel{0}{0} \\
\text { II }\end{array}$ & $\stackrel{S}{2}$ & $\stackrel{n}{2}$ \\
\hline PEOU6 & .000 & & & & & & & & & & & & \\
\hline PU 3 & 1.546 & .000 & & & & & & & & & & & \\
\hline $\mathrm{BI} 3$ & .524 & .458 & .000 & & & & & & & & & & \\
\hline BI2 & 1.719 & -.355 & .000 & .000 & & & & & & & & & \\
\hline BI1 & 1.844 & .066 & -.439 & .027 & .000 & & & & & & & & \\
\hline A4 & 1.284 & -.401 & -.070 & -.237 & -.039 & .000 & & & & & & & \\
\hline A2 & 1.968 & .809 & .197 & -.033 & .167 & .067 & .000 & & & & & & \\
\hline A1 & 1.480 & -.635 & .535 & .194 & -.102 & .157 & -.214 & .000 & & & & & \\
\hline PEOU1 & -.309 & .167 & -1.294 & -.329 & .106 & -.930 & .029 & -.659 & .000 & & & & \\
\hline PEOU2 & -.153 & .510 & -.961 & -.323 & .179 & -.531 & .195 & -.014 & .112 & .000 & & & \\
\hline PEOU4 & .603 & 1.407 & .957 & -.019 & -1.147 & .187 & -.010 & -.225 & .184 & -.223 & .000 & & \\
\hline PU2 & .562 & .044 & .364 & .159 & -.152 & .060 & -.531 & -.087 & -.643 & .012 & -.935 & .000 & \\
\hline PU 5 & -.082 & -.347 & .578 & .311 & -.103 & 1.497 & .244 & 2.382 & -.475 & -.503 & 1.201 & .063 & .00 \\
\hline
\end{tabular}


Table 4. Structural Model and Hypothesis testing

Tabelle 4. Strukturiertes Model und Hypothesentest

\begin{tabular}{|c|c|c|c|}
\hline Hypothesis & Paths & Coefficient & $p$-value \\
\hline $\mathrm{H}_{1}$ & $\mathrm{INT} \leftarrow \mathrm{PU}$ & 1.108 & $0.084^{*}$ \\
\hline $\mathrm{H}_{2}$ & $\mathrm{INT} \leftarrow \mathrm{ATT}$ & 1.192 & $0.000^{* \ldots+}$ \\
\hline $\mathrm{H}_{3}^{2}$ & $\mathrm{ATT} \leftarrow \mathrm{PEOU}$ & 0.184 & $0.210^{*}$ \\
\hline $\mathrm{H}_{4}$ & $\mathrm{PU} \leftarrow \mathrm{PEOU}$ & 0.153 & $0.093^{*}$ \\
\hline $\mathrm{H}_{5}$ & $\mathrm{ATT} \leftarrow \mathrm{PU}$ & 1.229 & $0.044^{* *}$ \\
\hline
\end{tabular}

* =not significant at the 0.05 level;

${ }^{* *}=$ significant at the 0.05 level;

$* * *=$ significant at the 0.001 level

As displayed by Table 4, the results indicate that the hypotheses test show that only two latent variables were statistically significant; at the 0.05 and the 0.01 levels.

The two hypotheses that were statistically significant are $\mathrm{H}_{2}$ and $\mathrm{H}_{5}$ :

- $\mathrm{H}_{2}(\mathrm{~A} \rightarrow \mathrm{INT})$ indicates that attitude toward usage has a positive effect on intention to use IP, and it confirms one of the basic premises of TAM. Then, the growers who have positive attitudes toward IP are more likely to adopt IP, since they have a higher intention in performing this behavior.

- $\mathrm{H}_{5}$ (PU $\rightarrow$ ATT), in turn, indicates that perceived usefulness has a positive effect on attitude to use IP. Then, the more respondents consider IP useful for their current farm's production conditions, during the period of the research, the higher is their attitude toward adopting IP.

Our model did not confirm the remaining three hypotheses:

- $\mathrm{H}_{1}$ (PU $\rightarrow$ INT): we expected that the positive effect of perceived usefulness on behavioral intention to use

Table 5. Standardized Regression Weights

Tabelle 5. Standardisierte Regressionsgewichte

\begin{tabular}{|c|c|c|c|}
\hline $\begin{array}{l}\text { Std. Regression } \\
\text { Weights }\end{array}$ & Estimate & $\begin{array}{c}\text { Std. Regression } \\
\text { Weights }\end{array}$ & Estimate \\
\hline $\mathrm{INT} \leftarrow \mathrm{PU}$ & 0.287 & peou $2 \longleftarrow \mathrm{PEOU}$ & 0.834 \\
\hline $\mathrm{INT} \leftarrow \mathrm{ATT}$ & 0.762 & peou $4 \leftarrow$ PEOU & 0.377 \\
\hline $\mathrm{A} \leftarrow \mathrm{PEOU}$ & 0.171 & peou $6 \leftarrow$ PEOU & 0.504 \\
\hline $\mathrm{PU} \leftarrow \mathrm{PEOU}$ & 0.351 & $\mathrm{a} 1 \leftarrow \mathrm{ATT}$ & 0.785 \\
\hline $\mathrm{ATT} \leftarrow \mathrm{PU}$ & 0.498 & $\mathrm{a} 2 \leftarrow \mathrm{ATT}$ & 0.818 \\
\hline $\mathrm{pu} 2 \leftarrow \mathrm{PU}$ & 0.767 & $\mathrm{a} 4 \leftarrow$ ATT & 0.807 \\
\hline $\mathrm{pu} 3 \leftarrow \mathrm{PU}$ & 0.512 & int $1 \leftarrow$ INT & 0.827 \\
\hline $\mathrm{pu} 5 \leftarrow \mathrm{PU}$ & 0.294 & int $2 \longleftarrow$ INT & 0.833 \\
\hline peoul $\leftarrow$ PEOU & 0.761 & int $3 \leftarrow$ INT & 0.514 \\
\hline
\end{tabular}

IP was significant. However, it was not. It means that a higher intention to adopt IP does not depend on the respondents' perception of usefulness of IP system. Actually, PU does not have a direct effect on intention, but an indirect effect by attitude $\left(\right.$ see $\left.\mathrm{H}_{5}\right)$. It means that other attitudinal factors besides those considered on PU are important to make growers adopt IP.

The other antecedent of attitude toward usage is the perceived ease of use (PEOU). Neither H3 nor H4 were significant according to the findings:

- $\mathrm{H}_{3}$ (PEOU $\rightarrow \mathrm{A}$ ): although perceived ease of use had a positive effect on attitude to use IP, its coefficient was not significant indicating that respondents do not believe that the more IP is perceived as easy to be applied, the higher is the attitude toward usage.

- $\mathrm{H}_{4}$ (PEOU $\left.\rightarrow \mathrm{PU}\right)$ : similarly, perceived ease of use showed a positive effect on perceived usefulness of IP, but non-significant. Then, the usefulness of IP is not directly influenced by the level of facility or difficulty in applying some IP practices.

The comprehension of these results can be improved by analyzing the standardized regression weights presented in Table 5.

The respondents perceived the factor 'pu2' as the most important to measure perceived usefulness. It means that whether they consider IP as a good technology to improve the agronomic effectiveness largely depends on whether they believe that it is associated to the application of good agricultural practices and specific standards of production. The second most important perception was about cost reduction especially with inputs, if they use IP ('pu3').

In terms of perceived ease of use, the most important factor to measure this construct was the fact the respondents believe that it would be easy for them to understand and apply the IP standards for common beans' production ('peou2). Similarly, to learn and apply most of the IP practices ('peou1') was also an important element of the PEOU construct.

The factors to measure attitude toward the behavior had almost the same level of importance in the construct measurement. The respondents' overall opinion of IP, the respondents' idea of using IP, and the respondents' decision of using IP were all important measurements. The less important factor to measure behavioral intention was ('bi3') the conditioned adoption to the neighboring farmer's adoption. 


\section{Concluding Remarks}

As mentioned in chapter 1, the Brazilian Government has been investing lots of money and efforts so as to encourage a greater production of quality/safe agro-foods by using the IP system, and other sustainable agricultural practices. However, the rates of adoption are not convincing.

In the present study, the Technology Acceptance Model (TAM) was applied in an attempt to provide an adequate explanation of adoption and use of IP by common beans' farmers. For the purpose of the present study, the TAM was tested with IP understood as a bundle of technologies. This study advanced our understanding on IP adoption by drawing on established adoption theory, and focusing on individual perceptions as important drivers of the adoption decision process. It sought to fill part of the gap that exists in the literature on the IP adoption in the Brazilian context. The findings evidence some determinants of the intention of beans' growers to adopt IP in one of the most important areas of beans' production in the Brazilian Central Region, where the conventional farming still dominates.

The TAM model explained partially the behavioral intention of IP adoption. Apparently, models such as TAM do not work very well on non-divisible technologies such as IP. Maybe, it is because the respondents cannot evaluate each comprised agricultural practice, individually. The model demonstrated that perceived usefulness (PU) has a positive effect on attitude (ATT), indicating that the respondents perceive IP as a useful production system.

In turn, respondents' attitude to use IP system was positively reinforced by its perceived usefulness of IP and consequently the positive attitude toward usage had a positive effect on intention to use IP. However, the model scored quite modestly in terms of significance level of the relationships among perceived usefulness of IP on growers' intention to adopt IP. This shows that our modification of Davis model should be rethought due to the relatively weakness of the findings. All in all, the main criticism on our model relies around the variable that Davis first labelled as perceived ease of use (PEOU). The expected positive effect of PEOU on PU of IP (H4: PEOU $\rightarrow$ PU) was not significant.

Our findings confirm previous studies that highlight how perceived usefulness (PU) scores significantly greater on attitude than PEOU. So, for instance, in the works of Flett et al. (2004) and Szajna (1996), PU had the greatest impact on the individual intention to use. However, in Davis' own research using TAM to test Internet use, PEOU appeared to be more important (Shih, 2004).

Probably, factors such as the frequent support of an agronomist to conduct the IP seem to be important to encourage growers to have a positive attitude towards adopting IP. Moreover, the unavailability of biological control agents was an important limiting factor to IP adoption, as well as the weakness technical support services such as monitoring and alert system of pest and diseases, meteorological station, and so on. According to the respondents' perceptions, the absence of some of these factors could cause some level of uncertainty. Thus, suppliers of biological products and IP technologies have a role to play in addressing this limitation.

Actually, factors related to the IP ease of use contribute to the slow process of IP's adoption among the studied community. As a matter of fact, the reluctance showed by the respondents during the face-to-face surveys is confirmed by the results of the SEM. Respondents did not believe that IP is very easy to use and adopt. The respondents perceived that IP requires more use of intensive workforce, mainly, for monitoring and agronomic records and documentation procedures. This is confirmed by the results of the qualitative interviews. According to interviewees, farm management is not yet in the stage of using a good and efficient information system. Moreover, availability of trained workforce is still low.

The fragility in terms of technical support availability in the region was another important element that influenced IP adoption. The respondents perceived that there could be difficulty to use IP without an intensive technical assistance. This result is convergent to the known fragility of the public extension services available to the producers and the technical capacity of the local technicians in IP issues. Furthermore, considering the complexity of some IP practices, and the various rules that have to be fulfilled, it is crucial to promote new training courses in the region to motivate the producers and give them confidence to implement IP in their farms. The results of this study pointed out that education plays an effective role in the adoption of IP. Hence, it is recommended that government may take actions to upgrade the education as well as training programs for beans producers and technicians.

Moreover, the compliance of several mandatory regulations in diverse fields such as financial, environmental, le$\mathrm{gal}$, and so on, is another factor that influences the process of IP adoption. In this case, it is fundamental to promote discussions with the public authorities to find solutions 
to reduce the legal bureaucracy, and to create some legal advantages for those who implement IP as a sustainable production system.

Overall, the respondents have a positive intention to use IP and recommend IP for other farmers. They demonstrate a positive attitude in adopting IP if their neighbors adopt. The aggregate adoption is fundamental to the success of IP dissemination in the long run.

The general conclusion is that growers will adopt IP when it is in their economic interest to do so, either because IP increases their net financial returns (as compared to other production systems) or maintains that return but with other desired, non-monetary benefits.

As recommendation, we suggest further studies to verify the intention of IP adoption by single crop versus mixed crops versus crop and livestock. The complexity of management in this latter situation could influence negatively the intention of IP adoption. Additionally, further studies to verify the intention of IP adoption in different levels of farm size is also indicated. Considering that farms in Brazil have huge land extensions, it could be more difficult to convince producers and/or their consultants in adopting IP; IP requires an intensive presence of technical support and a more complex information system to provide the agronomic records and documentation as foreseen by the IP standards.

Our findings offer rich elements to suggest a new approach of technology transfer aiming to the process of IP adoption, taking into consideration the actors' perceptions toward the studied technology. The findings also suggest opportunities for development of new solutions by some key-agents of the production chain to support the IP usage. Additionally, the results can contribute with several important implications for the research community, policy makers, and agribusiness stakeholders in terms of economic, social, technical, environmental, and market factors. However, the proposed model only partially explains IP adoption intentions

\section{References}

Adrian, A.M., Norwood, S.H. and P.L. Mask (2005): Producers' perceptions and attitudes toward precision agriculture technologies. Computers and Electronics in Agriculture 48, 256-271.

Ajzen, I. and M. Fishbein (1980): Understanding Attitudes and Predicting Social Behavior. Prentice-Hall, Englewood Cliffs, New Jersey.
Alves da Costa Filho, B., Pires, P.J. and J. Costa Hernandez (2007): Model Technology Acceptance Model - TAM aplicado aos automated teller machines - ATM's. RAI Revista de Administração e Inovação 4, 40-56.

Andrigueto, J.R., Nasser, L.C.B., Teixeira, J.M.A., Simon, G., Veras, M.C.V., Medeiros, S.A.F., Souto, R.F., Martins, M.V. and A.R. Kososki (2009): Produção Integrada de Frutas e Sistema Agropecuário de Produção Integrada no Brasil. In: Produção Integrada no Brasil: agropecuária sustentável, alimentos seguros. MAPA/ ACS, Brasília, 33-58.

Ascough II, J.C., Hoag, D.L., Frasier, W.M. and G.S. McMaster (1999): Computer use in agriculture: an analysis of Great Plains producers. Computers and Electronics in Agriculture 23, 189-204.

Aubert, B.A., Schroeder, A. and J. Grimaudo (2012): IT as enabler of sustainable farming: an empirical analysis of farmers' adoption decision of precision agriculture technology. Decision Support Systems 54, 510-520.

BRASIL (2010): Instrução Normativa N.27, de 30 de Agosto de 2010. Diretrizes gerais com vistas a fixar preceitos e orientaçóes para os programas e projetos que fomentem e desenvolvam a Produção Integrada Agropecuária (PI-Brasil) (Vols. 167, Seção 1, 7). Diário Oficial da União, Brasília.

BRASIL (2015): Produção Integrada da Cadeia Agrícola. http://www.agricultura.gov.br/desenvolvimento-sustentavel/producao-integrada. Accessed on 14 September 2015.

Byrne, B.M. (2009): Structural equation modeling wity AMOS: basic concepts, applications, and programming. $2^{\text {nd }}$ ed., Routledge, New York.

Chin, W.C. and P.A. Todd (1995): On the use, usefulness and ease of use of structural equation modeling in MIS research: a note of caution. MIS Quarterly 19, 237-246.

Daberkow, S.G. and W.D. McBride (2003): Farm and operator characteristics affecting the awareness and adoption of precision agriculture technologies in the US. Precision Agriculture 4, 163-177.

Davis, F.D. (1989): Perceived usefulness, perceived ease of use, and user acceptance of information technology. MIS Quarterly 13, 319-340.

Davis, F.D., Bagozzi, R.P. and P.R. Warshaw (1989): User acceptance of computer technology: a comparison of two theoretical models. Management Science 35, 982-1003.

Fishbein, M. and I. Ajzen (1975): Belief, attitude, intention, and behavior: an introduction to Theory and Research. Addison-Wesley, Reading, MA, USA. 
Flett, R., Alpass, F., Humphries, S., Massey, C., Morriss, S. and N. Long (2004): The technology acceptance model and use of technology in New Zealand dairy farming. Agricultural Systems, 80, 199-211.

Folorunso, O. and S.O. Ogunseye (2008): Applying an enhanced technology acceptance model to knowledge management in agricultural extension services. Data Science Journal, 7, 31-45.

Francis, J.J., Eccles, M.P., Johnston, M., Walker, A., Grimshaw, J., Foy, R., Kaner, E.F.S., Smith, L. and D. Bonetti (2004): Constructing questionnaires based on the theory of planned behaviour. A manual for health services researchers. University of Newcastle, Centre of Health Services Research, Newcastle, UK.

Gasson, R., Crow, G., Errington, A.J., Hutson, J., Marsden, T. and D.M. Winter (1988): The farm family business: a review. Journal of Agricultural Economics 39, 1-14.

Hair, J., Black, W.C., Babin, B.J., Anderson, R.E. and R.L. Tatham (2006): Multivariate Data Analysis. Pearson Prentice Hall, Upper Saddle River, New Jersey.

Hussain, M., Zia, S. and A. Saboor (2011): The adoption of integrated pest management (IPM) technologies by cotton growers in the Punjab. Soil and Environment 30, $74-77$.

Kline, R.B. (2011): Principles and practice of structural equation modeling. $3^{\text {rd }}$ ed., The Guilford Press, New York.

Lee, Y.-H., Hsieh, Y.-C. and C.-N. Hsu (2011): Adding Innovation Diffusion Theory to the Technology Acceptance Model: supporting employees' intentions to use e-learning systems. Educational Technology \& Society $14,124-137$.

Li, J., Gómez, M.I., Rickard, B.J. and S. Margaret (2013): Factors influencing adoption of integrated pest management in Northeast greenhouse and nursery production. Agricultural and Resource Economics Review 42, 310-324.

Lusk, J.L. (2002): Effects of cheap talk on consumer willingness-to-pay for golden rice. American Agricultural Economics Association Annual Meeting. 28-31 July 2002, Long Beach, California.

Morris, M.G. and V. Venkatesh (2000): Age differences in technology adoption decisions: implications for a changing workforce. Personnel Psychology 53, 375-403.

Moser, C.M. and C.B. Barrett (2003): The disappointing adoption dynamics of a yield-increasing, low external- input technology: the case of SRI in Madagascar. Agricultural Systems 76, 1085-1100.

Parvan, A. (2011): Agricultural Technology Adoption: issues for consideration when scaling-up. The Cornell Policy Review 1, 5-31.

Rogers, E.M. (1995): Diffusion of Innovations. $4^{\text {th }}$ ed., Free Press, New York.

Shih, H-P. (2004): Extended technology acceptance model of Internet utilization behavior" in Information \& Management 41, 719-729.

Silva, A.M. (2005): A influência do treinamento de usuários na aceitação de sistemas ERP em empresas no Brasil. Universidade Federal do Rio de Janeiro, Rio de Janeiro.

Silva, A.G., Wander A.E., Barbosa, F.R., Gonzaga, A.C. de Oliveira and J.G. da Silva (2012): Análise econômica da produçáo de feijáo comum em sistema de produção convencional e de produção integrada, em Cristalina, Estado de Goiás, e Unaí, Estado de Minas Gerais, Maio de 2009 a Abril de 2010. Informaçóes Econômicas, 42, 55-64.

Sinden, J.A. and D.A. King (1990): Adoption of soil conservation measures in Manilla Shire, New South Wales. Review of Marketing and Agricultural Economics 58, 179-192.

Souza Filho, H.M., Buainain, A.M., Jardim da Silveira, J.F. and M.B. Vinholis (2011): Condicionantes da adoção de inovaçóes tecnológicas na agricultura. Cadernos de Ciência \& Tecnologia 28, 223-255.

Sterns, J.A. and J.-M. Codron (2001): Why adopt integrated crop production? A perspective from the French fruit sector. American Agricultural Economics Association's 2001 Annual Meeting, 5-8 August 2001, Chicago, Illinois, number 20715.

Szajna, B. (1996): Empirical evaluation of the revised technology acceptance model. Management Science 42, $85-92$.

Van den Berg, H. and J. Jiggins (2007): Investing in farmers-the impacts of farmer field schools in relation to integrated pest management. World Development 35, 663-686.

Vommi, H.K., LaVergne, D.D. and S.A. Gartin (2013): Growers' Perceptions and Adoption Practices of Integrated Pest Management in West Virginia. Journal of Extension 51, 1-9. 